\title{
BUDIDAYA KERANG HIJAU (Perna viridis L.) DENGAN METODE DAN KEPADATAN BERBEDA DI PERAIRAN PESISIR KUALA LANGSA, ACEH
}

\author{
Andi Sagita, Rahmat Kurnia, dan Sulistiono \\ Departemen Manajemen Sumberdaya Perairan, Institut Pertanian Bogor \\ (Naskah diterima: 4 Januari 2017; Revisi final: 20 Maret 2017; Disetujui publikasi: 21 Maret 2017)
}

\begin{abstract}
ABSTRAK
Kerang hijau merupakan komoditas budidaya laut yang sangat prospektif untuk dikembangkan pada suatu sistem budidaya, karena dapat dilakukan dengan biaya produksi yang rendah namun menghasilkan profitabilitas yang tinggi. Penelitian ini bertujuan untuk mengetahui metode dan kepadatan yang paling optimal untuk budidaya kerang hijau di perairan pesisir Kuala Langsa, Aceh. Metode penelitian menggunakan rancangan acak lengkap faktorial yang terdiri atas faktor metode (long line dan stick) dan faktor kepadatan (20, 30, dan 40 individu/kantong 5,30 L), masing-masing diulang sebanyak empat kali. Berdasarkan sidik ragam data Specific Growth Rate (SGR) dari panjang (SGL L) dan bobot (SGR W) menunjukkan semua perlakuan metode, kepadatan dan interaksi berbeda signifikan pada taraf uji $5 \%(P<0,05)$, di mana perlakuan yang paling optimal yaitu perlakuan metode long line dengan kepadatan 20 individu/kantong 5,30 L diperoleh rata-rata nilai SGR (L) sebesar $0,86 \pm 0,01 \%$ hhari dan SGR (W) sebesar 1,18 $\pm 0,04 \%$ hhari dengan sintasan mencapai $92,50 \pm 2,89 \%$ Parameter kualitas perairan selama periode budidaya masih sesuai untuk mendukung kehidupan kerang hijau di mana suhu berkisar $27,5-34,0^{\circ} \mathrm{C}$; salinitas $28,5-33,0 \mathrm{ppt}$; pH 7,88,6; dan oksigen terlarut 4,5-6,5 mg/L; serta kecepatan arus 0,1-0,3 m/s. Budidaya kerang hijau dengan metode long line pada kepadatan 20 individu/kantong 5,30 L merupakan pola budidaya yang paling optimal untuk diterapkan di perairan pesisir Kuala Langsa, Aceh.
\end{abstract}

KATA KUNCl: budidaya; metode; kepadatan; kerang hijau; Kuala Langsa

ABSTRACT: Green mussel (Perna viridis $L$.) culture with different methods and densities in coastal waters Kuala Langsa, Aceh. By: Andi Sagita, Rahmat Kurnia, and Sulistiono

Green mussel is a very prospective marine aquaculture commodity due to its low cost production but with high profitability. This research aimed to determine the most optimal method and densities for green mussel culture in coastal waters of Kuala Langsa, Aceh. The research used a completely randomized factorial design consisting of methods factor (long line and stick) and densities factor (20,30, and 40 individuals/basket $5.30 \mathrm{~L}$ ), each repeated four times. Based on the variance analysis of specific growth rate (SGR) data of the length (SGR L) and weight (SGR W), all treatments of different methods and densities as well as their interactions were significant different $(P<0.05)$. This study suggested that long line method with a densities of 20 individuals/basket $5.30 \mathrm{~L}$ was found to be the most optimal treatment for green mussel culture in coastal waters of Kuala Langsa. With this long line method an average SGR (L) value of $0.86 \pm 0.01 \%$ day, SGR (W) value of $1.18 \pm 0.04 \%$ day, and survival rate of $92.50 \pm 2.89 \%$ were obtained. Water quality parameters during the culture period are still within the suitable rangefor green mussel culture, with the range of temperature $27.5-34.0^{\circ} \mathrm{C}$, salinity $28.5-33.0 \mathrm{ppt}$, pH 7.8-8.6, dissolved oxygen 4.5-6.5 mg/L, and current velocity $0.1-0.3 \mathrm{~m} / \mathrm{s}$.

KEYWORDS: culture; method; densities; green mussel; Kuala Langsa

\footnotetext{
\# Korespondensi: Departemen Manajemen Sumberdaya Perairan, Institut Pertanian Bogor. Jl. Agatis Kampus IPB Darmaga, Bogor, Jawa Barat 16680, Indonesia.

Tel. + (0251) 8622909

E-mail: andisagita2@gmail.com
} 


\section{PENDAHULUAN}

The green-lipped mussel atau asian green mussel atau disebut kerang hijau merupakan famili M ytilidae yang termasuk spesies Perna viridis L. dan merupakan komoditas penting budidaya laut (Gosling, 2003). Kerang hijau juga termasuk salah satu jenis biota kekerangan yang prospektif untuk dikembangkan dalam suatu sistem budidaya karena pertumbuhannya yang cepat dan dapat dilakukan sepanjang tahun, serta diketahui memiliki toleransi yang tinggi terhadap berbagai kondisi lingkungan, sehingga menguntungkan secara ekonomis untuk suatu sistem budidaya (Rajagopal et al., 2003; Sallih, 2005).

Faktor yang mendorong pengembangan budidaya kerang hijau antara lain tingkat pertumbuhan kerang hijau yang relatif cepat sehingga periode budidaya lebih pendek untuk mencapai ukuran konsumsi, selain itu, ketersediaan benih dari alam sepanjang tahun tanpa perlu proses pembenihan (Soon \& Ransangan, 2014). Budidaya kerang hijau dapat dilakukan dengan biaya produksi yang rendah namun menghasilkan profitabilitas yang tinggi (Acosta et al., 2009), selain itu, budidaya tersebut tidak berdampak terhadap penurunan kualitas lingkungan (Ellis et al., 2002), serta tergolong kegiatan budidaya yang ramah lingkungan (Shumway et al., 2003) sehingga dapat dilakukan secara berkelanjutan (Costa-Pierce, 2008).

Pesatnya perkembangan budidaya kerang hijau disebabkan oleh mudahnya teknik budidaya spesies tersebut, dibandingkan dengan teknologi biota budidaya lainnya. Peningkatan produksi kegiatan budidaya dapat dilakukan dengan memanipulasi sistem atau teknik budidaya untuk meningkatkan kualitas maupun kuantitas produk hasil budidaya (Cheney, 2010). Meto de budidaya kerang hijau yang telah banyak diterapkan di Indonesia, antara lain metode tancap, rakit tancap, rakit apung, dan long line (Rejeki, 2001), sedangkan penerapan kepadatan kerang hijau pada proses budidaya belum banyak dikaji, hal tersebut dikarenakan masyarakat lebih menyukai mengumpulkan kerang hijau langsung di perairan pesisir tanpa perlu proses budidaya. Kajian tentang pola budidaya kerang hijau yang sesuai dengan kondisi lingkungan perlu dilakukan, mengingat praktek manajemen budidaya akan lebih optimal dan efektif bila dilakukan dengan kepadatan dan metode yang sesuai sehingga akan mengimbangi biaya produksi dari kegiatan budidaya tersebut untuk menghasilkan keuntungan yang maksimal.

Kegiatan penangkapan kerang hijau di perairan pesisir Kuala Langsa telah dilakukan masyarakat setempat baik menggunakan alat, seperti garuk, maupun dengan mengumpulkan tanpa alat. Berdasarkan hasil observasi, perairan pesisir Kuala Langsa mempunyai kedalaman yang sesuai untuk kegiatan budidaya laut khususnya kerang hijau yaitu berkisar 2 $\mathrm{m}$ hingga $7 \mathrm{~m}$ dan daerah tersebut bersubstrat pasir berlumpur. Pertimbangan-pertimbangan tersebut yang menjadi asumsi bahwa biota kerang hijau yang selama ini menjadi salah satu komoditas tangkapan di pesisir Kuala Langsa memiliki potensi untuk dibudidayakan. Namun, untuk mengetahui tingkat produktivitas budidaya kerang hijau pada lokasi penelitian perlu dilakukan uji coba budidaya dengan mempertimbangan kepadatan dan metode yang sesuai. Prinsipnya metode budidaya kerang hijau yang diujico bakan pada perairan pesisir Kuala Langsa, sama dengan metode budidaya kerang hijau lainnya. Penerapan metode yang berbeda hanya untuk mengetahui hasil produksi dan tingkat produktivitas budidaya kerang hijau jika dilakukan di perairan pesisir Kuala Langsa.

Penelitian ini penting untuk dilakukan karena metode dan pola budidaya yang digunakan dalam kegiatan budidaya dapat memengaruhi produktivitas budidaya yang dilakukan, yang pada akhirnya juga akan memengaruhi manfaat ekonominya, di mana metode budidaya memiliki efektivitas yang berbeda satu sama lain yang juga berkaitan dengan kondisi lokasi budidayanya. Penelitian ini bertujuan untuk mengetahui metode dan kepadatan yang paling optimal untuk budidaya kerang hijau di perairan pesisir Kuala Langsa, Aceh.

\section{BAHAN DAN METODE}

\section{Waktu dan Tempat Percobaan}

Penelitian ini dilakukan pada Juli hingga September 2016, di perairan pesisir Kuala Langsa, Langsa Provinsi Aceh, yang merupakan pesisir Barat Kota Langsa yang berbatasan langsung dengan Selat Malaka. Penentuan lokasi budidaya kerang hijau dilakukan secara sengaja (purposive) dengan pertimbangan bahwa lokasi yang terpilih terdapat struktur penahan abrasi yang berupa hard barrier (tanggul penahan abrasi) maupun soft barrier (mangrove) yang secara tidak langsung membentuk kawasan perairan yang relatif tenang yang berbentuk seperti kolam sehingga lokasi tersebut relatif terlindung dari faktor-faktor hidrooseanografi yang dapat merusak konstruksi budidaya, seperti gelombang, angin dan pasang surut, serta faktor lainnya. Lokasi perairan pesisir Kuala Langsa memiliki rata-rata pasang surut air laut tercatat hanya berkisar $1 \mathrm{~m}$, namun lokasi terpilih merupakan tempat budidaya yang pada saat pasang dan surut selalu terendam air sehingga tidak berpengaruh signifikan terhadap kondisi kerang hijau selama periode budidaya. 


\section{Rancangan dan Unit Percobaan}

Rancangan percobaan yang digunakan pada penelitian ini adalah rancangan acak lengkap dengan perlakuan faktorial (RALF). RALF digunakan karena lokasi yang digunakan untuk kegiatan budidaya relatif homogen, sehingga pengacakan tidak akan memberikan pengaruh yang signifikan terhadap hasil budidaya. Rancangan penelitian faktorial ini terdiri atas faktor metode (A) yaitu metode long line (A1) dan stick (A2) dan faktor kepadatan (B) yaitu kepadatan 20 (B1), 30 (B2), dan 40 (B3) individu/kantong. Perlakuan pada penelitian ini terdiri atas perlakuan A1B1 (long line, 20 individu/kantong), A1B2 (long line, 30 individu/ kantong), A1B3 (long line, 40 individu/kantong), A2B1 (stick, 20 individu/kantong), A2B2 (stick, 30 individu/ kantong), dan A2B3 (stick, 40 individu/kantong), serta masing-masing perlakuan diulang sebanyak empat kali.

Penelitian ini dimulai dengan membuat kantong untuk menempatkan benih kerang hijau selama periode budidaya yang disebut kreneng yang terbuat dari anyaman bambu. Kreneng berbentuk seperti tabung berdiameter $15 \mathrm{~cm}$ dan tinggi $30 \mathrm{~cm}$ sehingga volume $\left(\pi r^{2} \mathrm{t}\right)$ kreneng sekitar 5,30 L.

Desain konstruksi metode long line mengacu pada Vakily (1989), Aypa (1990), dan Kripa \& Mohamed (2008). Konstruksi long line menggunakan dua buah tiang bambu dengan tinggi 2,5 m yang ditancapkan pada kedalaman perairan 1,5 m; kemudian tali nilon berdiameter $5 \mathrm{~mm}$ sepanjang $2 \mathrm{~m}$ diikatkan secara horizontal pada masing-masing bambu. Mussel rope atau kreneng diikatkan mengantung pada tali nilon dengan jarak dari permukaan perairan yaitu $0,5 \mathrm{~m}$; sedangkan jarak antar kreneng yaitu 0,7 m. Satu unit konstruksi long line terdiri atas tiga kreneng untuk masing-masing perlakuan A1B1, A1B2, dan A1B3. Desain metode long line selengkapnya dapat dilihat pada Gambar 1.

Konstruksi stick mengacu pada Aypa (1990), yaitu menggunakan tiang bambu dengan tinggi $\pm 2,5 \mathrm{~m}$ yang ditancapkan pada kedalaman perairan $1,5 \mathrm{~m}$; kemudian kreneng dimasukkan ke dalam tiang bambu dengan jarak dari permukaan perairan adalah $0,5 \mathrm{~m}$. Satu unit konstruksi stick terdiri atas tiga kreneng untuk masing-masing perlakuan A2B1, A2B2, dan A2B3. Desain konstruksi stickselengkapnya dapat dilihat pada Gambar 2.

\section{Hewan Uji}

Spat atau benih kerang hijau yang digunakan pada penelitian diperoleh dengan cara mengumpulkan spat dari alam dengan menggunakan tali kolektor yang terbuat dari serabut kelapa, tali nilon, dan pintalan ijuk. Tali kolektor ditempatkan di perairan pesisir pada kedalaman 2-5 m selama kurang lebih empat minggu, di mana secara alamiah spat kerang hijau akan menempel pada tali kolektor, kemudian spat tersebut disortir untuk mengetahui panjang dan bobot yang mempunyai kisaran rata-rata sama. Spat kerang hijau yang digunakan pada awal penelitian yaitu dengan panjang rata-rata 19,2 $\pm 0,11 \mathrm{~mm}$ dan bobot ratarata $2,23 \pm 0,01 \mathrm{~g}$.

\section{Pengumpulan dan Analisis Data}

Periode budidaya kerang hijau dilakukan selama 60 hari. Data yang dikumpulkan meliputi bobot dengan menimbang kerang hijau menggunakan timbangan elektronik ketelitian 0,001 g; sedangkan data panjang kerang hijau menggunakan penggaris ketelitian 0,1 $\mathrm{mm}$. Data yang diperoleh kemudian dianalisis terhadap faktor-faktor yang berkaitan dengan parameter yang diukur yaitu Spesific Growth Rate (SGR \%hari) dari panjang (SGL L) dan bobot (SGR W) kerang hijau, yang dihitung menggunakan persamaan 1 dan 2 mengacu pada Hopkins (1992) dan Sreedevi et al. (2014) sebagai berikut:

$$
\begin{aligned}
& \operatorname{SGR}(\mathrm{L})=\frac{\operatorname{Ln~}_{t}-\operatorname{Ln} \mathrm{L}_{0}}{t} \times 100 \% \ldots \ldots \\
& \operatorname{SGR}(\mathrm{W})=\frac{\operatorname{Ln} \mathrm{W}_{t}-\operatorname{Ln} \mathrm{W}_{0}}{t} \times 100 \%
\end{aligned}
$$

di mana: $\quad \mathrm{L}_{0}$ adalah panjang awal $(\mathrm{mm})$ dan $\mathrm{L}_{\mathrm{t}}$ adalah panjang akhir $(\mathrm{mm})$ kerang hijau, serta $\mathrm{W}_{0}$ adalah bo bot awal (g) dan $\mathrm{W}_{\mathrm{t}}$ adalah bo bot akhir (g) kerang hijau selama periode budidaya (t)

Nilai sintasan atau survival rate (SR) kerang hijau selama periode budidaya juga dihitung menggunakan persamaan 3 berikut:

$$
\text { Sintasan }=\frac{N_{t}}{N_{0}} \times 100 \%
$$

di mana: $\quad \mathrm{N}_{0}$ adalah jumlah kerang hijau (individu) awal penelitian dan $\mathrm{N}_{\mathrm{t}}$ adalah jumlah kerang hijau (individu) pada akhir periode budidaya (t)

Pengamatan terhadap struktur komunitas plankton juga dilakukan sebagai data pendukung. Pengambilan sampel plankton dilakukan dengan menyaring air sebanyak $100 \mathrm{~mL}$ pada kedalaman $1 \mathrm{~m}$ dari permukaan menggunakan plankton net ke dalam botol sampel dengan volume $100 \mathrm{~mL}$. Sampel yang sudah diambil kemudian diawetkan dengan larutan formalin konsentrasi 4\% Sampel plankton kemudian 


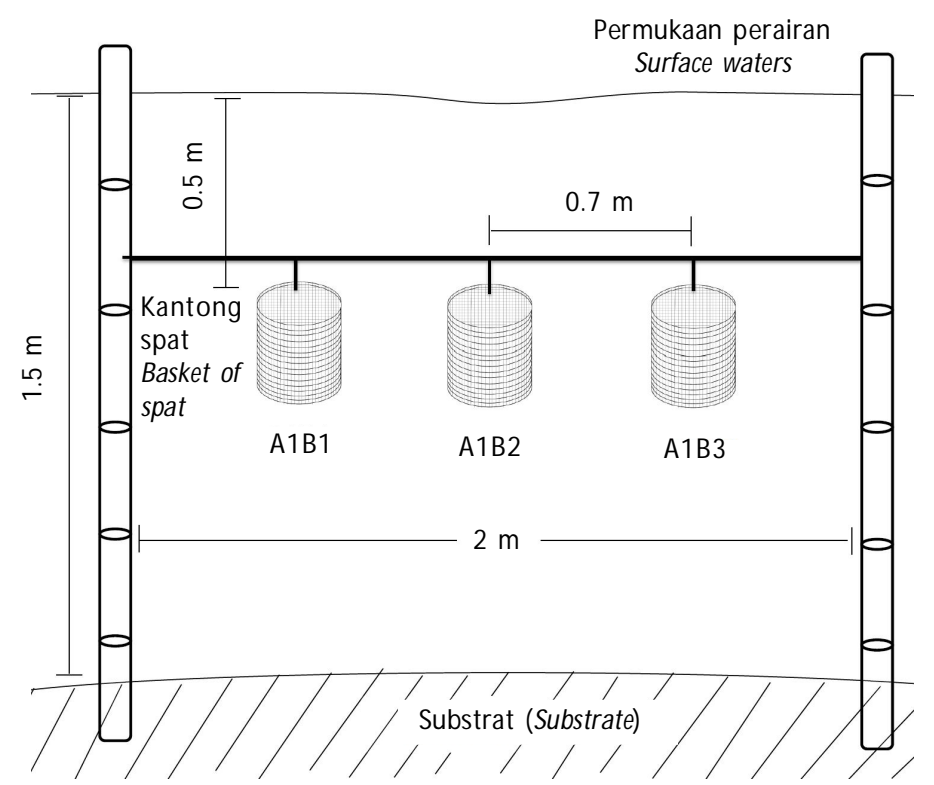

Gambar 1. Konstruksi metode long line yang diterapkan pada budidaya kerang hijau di perairan pesisir Kuala Langsa, Aceh

Figure 1. Construction of long line method applied to the green mussel culture in coastal waters Kuala Langsa, Aceh

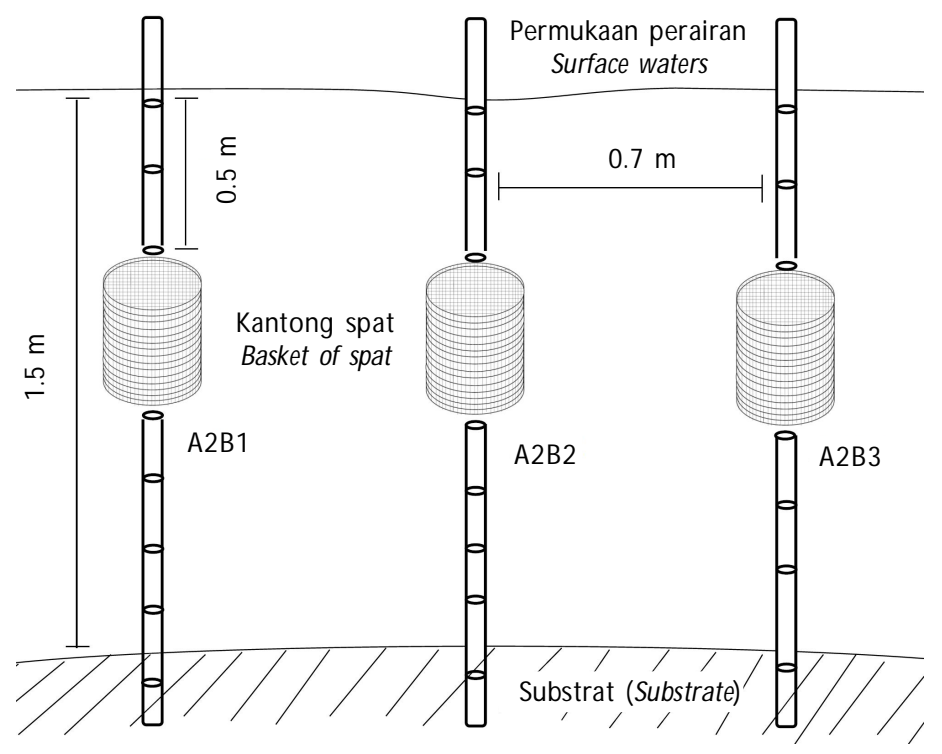

Gambar 2. Konstruksi metode stick yang diterapkan pada budidaya kerang hijau di perairan pesisir Kuala Langsa, Aceh

Figure 2. Construction of stick method applied on the green mussel culture in coastal waters Kuala Langsa, Aceh

diidentifikasi mengacu pada Davis (1955), kemudian dihitung kelimpahannya menggunakan sedgwick-rafter counting method dengan teknik sapuan dan diperoleh adalah satuan individu/m³.

Parameter hidrologi perairan juga diukur secara in situ selama periode budidaya yang meliputi suhu perairan, $\mathrm{pH}$, salinitas, dan oksigen terlarut menggunakan alat Water Quality Checker (WQC), sedangkan pengukuran kecepatan arus menggunakan current meter. Pengukuran hidrologi perairan dilakukan seminggu sekali pada pagi (08.00), siang (13.00), dan sore (16.00) hari selama periode budidaya (60 hari).

Analisis data dilakukan dengan sidik ragam untuk mengetahui apakah terdapat perbedaan yang signifikan dari SGR (L) dan SGR (W), serta sintasan kerang hijau pada masing-masing perlakuan. Jika ada perbedaan yang 
signifikan maka dilanjutnya dengan uji Beda Nyata Terkecil (BNT). Data hidrologi perairan dan plankton dianalisis secara deskriptif kualitatif dan kuantitatif.

\section{HASIL DAN BAHASAN}

Hasil penelitian menunjukkan bahwa semua perlakuan budidaya dengan perbedaan metode dan kepadatan menunjukkan peningkatan panjang dan bobot, di mana perlakuan yang mengalami pertumbuhan paling tinggi yaitu perlakuan A1B1 (metode long line dengan kepadatan 20 individu/ kantong 5,30 L) dengan panjang akhir mencapai 32,24 $\pm 0,21 \mathrm{~mm}$ dan bobot akhir sebesar 4,54 $\pm 0,12 \mathrm{~g}$; dengan SGR (L) sebesar 0,86 $\pm 0,01 \%$ hhari dan SGR (W) sebesar $1,18 \pm 0,04 \%$ hari dengan sintasan sebesar $92,50 \pm 2,89 \%$ (Tabel 1). Perlakuan yang memiliki pertumbuhan paling rendah adalah perlakuan A2B3 yaitu budidaya kerang hijau dengan metode stick pada kepadatan 40 individu/kantong 5,30 L; di mana pertumbuhan kerang hijau pada akhir penelitian sebesar 30,39 $\pm 0,75 \mathrm{~mm}$ dan bobot akhir 4,09 \pm $0,44 \mathrm{~g}$; serta nilai SGR (L) sebesar $0,76 \pm 0,04 \%$ hari dan $1,00 \pm 0,19 \%$ /hari untuk SGR (W) dengan sintasan sebesar $82,50 \pm 3,54 \%$

Hasil sidik ragam data SGR (L) dan SGR (W) menunjukkan adanya perbedaan yang signifikan pada masing-masing perlakuan metode dan kepadatan, serta adanya interaksi antara kedua faktor tersebut di mana
$\mathrm{P}<0,05$ (Lampiran 1 dan 2). Rata-rata SGR (L) dan SGR (W) kerang hijau yang dibudidayakan dengan metode dan kepadatan berbeda tersaji pada Tabel 1 .

Berdasarkan hasil sidik ragam data sintasan menunjukkan jika hanya faktor kepadatan yang berpengaruh terhadap sintasan kerang hijau, sedangkan faktor metode budidaya dan interaksi antar faktor tidak menunjukkan pengaruh yang signifikan terhadap sintasan kerang hijau (Lampiran 3). Rata-rata sintasan kerang hijau yang dibudidayakan dengan metode dan kepadatan berbeda tersaji pada Tabel 2 .

Perlakuan kepadatan 20 individu/kantong 5,30 L memiliki sintasan paling tinggi, dibandingkan perlakuan kepadatan 30 dan 40 individu/kantong 5,30 L; sehingga dapat disimpulkan bahwa semakin tinggi kepadatan semakin rendah sintasan dan pertumbuhan kerang hijau (Gambar 4).

Peningkatan kepadatan kerang hijau cenderung menurunkan laju pertumbuhan bobot baik pada metode long line maupun stick (Gambar 4). Menurut Leimena et al. (2005), kepadatan yang tinggi akan menyebabkan terjadinya predasi atau kompetisi, organisme saling berkompetisi memperebutkan ruang atau tempat, makanan, serta faktor lainnya. Kompetisi dalam ruang akan meningkatkan agresi antar organisme akuatik yang berujung pada kematian (Manley et al., 2014). Penelitian Garr et al. (2011),

Tabel 1. Rata-rata SGR (L) dan SGR (W) kerang hijau yang dibudidayakan dengan metode dan kepadatan berbeda di perairan pesisir Kuala Langsa, Aceh

Table 1. The average SGR (L) and SGR (W) of green mussel are cultured with defferent of method and densities in coastal waters Kuala Langsa, Aceh

\begin{tabular}{ccc}
\hline $\begin{array}{c}\text { Perlakuan } \\
\text { Treatments }\end{array}$ & SGR (L) (\%hari) & SGR (W) (\%) (\%hari) \\
\hline A1B1 & $0.86 \pm 0.01^{\mathrm{a}}$ & $1.18 \pm 0.04^{\mathrm{a}}$ \\
$\mathrm{A} 1 \mathrm{~B} 2$ & $0.83 \pm 0.03^{\mathrm{b}}$ & $1.15 \pm 0.05^{\mathrm{b}}$ \\
$\mathrm{A} 1 \mathrm{~B} 3$ & $0.82 \pm 0.04^{\mathrm{c}}$ & $1.10 \pm 0.23^{\mathrm{c}}$ \\
$\mathrm{A} 2 \mathrm{~B} 1$ & $0.81 \pm 0.01^{\mathrm{d}}$ & $1.05 \pm 0.08^{\mathrm{d}}$ \\
$\mathrm{A} 2 \mathrm{~B} 2$ & $0.78 \pm 0.03^{\mathrm{e}}$ & $1.00 \pm 0.09^{\mathrm{e}}$ \\
$\mathrm{A} 2 \mathrm{~B} 3$ & $0.76 \pm 0.04^{\mathrm{e}}$ & $1.00 \pm 0.19^{\mathrm{e}}$ \\
\hline Keterangan (Note): & $\begin{array}{l}\text { Huruf superskrip di belakang } \\
\text { nilai standar deviasi yang }\end{array}$ \\
& berbeda pada tiap kolom \\
& menunjukkan berbeda \\
& sangat nyata (P<0,05) (The \\
& value followed by different \\
& superscript in the same olumn \\
& were significantly different \\
& $(\mathrm{P}<0.05)$ )
\end{tabular}


Tabel 2. Rata-rata sintasan kerang hijau yang dibudidayakan dengan metode dan kepadatan berbeda di perairan pesisir Kuala Langsa, Aceh

Table 2. The average of survival rate of green mussel cultured with different methods and densities in coastal waters of Kuala Langsa, Aceh

\begin{tabular}{cc}
\hline $\begin{array}{c}\text { Perlakuan } \\
\text { Treatments }\end{array}$ & $\begin{array}{c}\text { Sintasan } \\
\text { Survival rate }(\%)\end{array}$ \\
\hline A1B1 & $92.50 \pm 2.89$ \\
A1B2 & $85.83 \pm 3.19$ \\
A1B3 & $83.75 \pm 3.23$ \\
A2B1 & $95.00 \pm 4.08$ \\
A2B2 & $86.67 \pm 2.72$ \\
A2B3 & $82.50 \pm 3.54$ \\
\hline
\end{tabular}

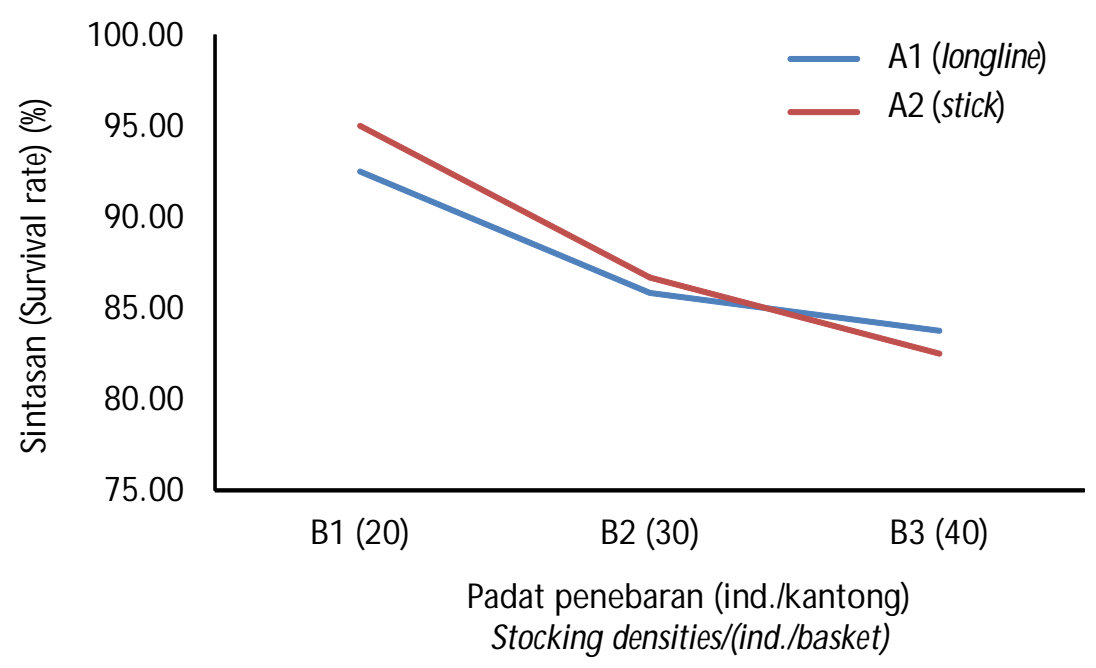

Gambar 3. Sintasan kerang hijau yang dibudidayakan pada metode dan kepadatan berbeda di perairan pesisir Kuala Langsa, Aceh

Figure 3. Survival rate of green mussel cultured with different methods and densities in coastal waters of Kuala Langsa, Aceh

menunjukkan adanya pengaruh kepadatan terhadap pertumbuhan, sintasan dan produksi Pomacea paludosa. Kepadatan juga berpotensi menyebabkan organisme menjadi stres yang akan memengaruhi fisiologi dan perilaku organisme, serta pertumbuhannya (Luo et al., 2013). Stres yang berkepanjangan atau kronis akan berpengaruh pada fisiologi dan sintasan (Huntingford \& Damsgard, 2012). Kepadatan yang tinggi juga menyebabkan menurunnya efisiensi pakan, meningkatnya konsumsi energi, mengurangi laju pakan, dan kecernaan Labeo victorianuson (Magondu et al., 2013).
Penggunaan metode long line untuk budidaya kerang hijau memiliki beberapa keunggulan di antaranya dapat dipelihara dengan sintasan yang tinggi, kemudian pemasangan tali pada long linememanfaatkan semua kolom permukaan perairan sehingga ketersediaan makanan bagi kerang hijau dapat terjadi secara optimal dan kepadatan yang sesuai akan memungkinkan pertumbuhan yang lebih seragam sehingga dapat diperkirakan waktu pemanenan. Penggunaan tali pada metode long line juga memudahkan dalam pengontrolan organisme predasi ataupun biofouling. Selain itu, penggunaan tali tidak 


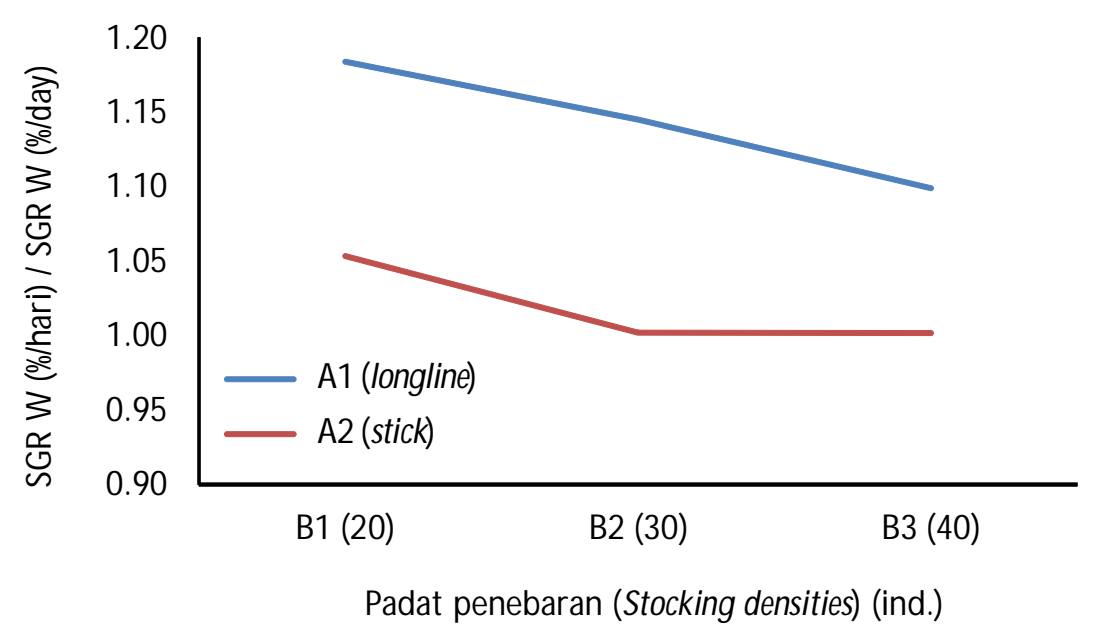

Gambar 4. SGR (W) kerang hijau yang dibudidayakan dengan metode dan kepadatan berbeda di perairan pesisir Kuala Langsa, Aceh

Figure 4. SGR (W) of green mussel cultured with different methods and densities in coastal waters of Kuala Langsa, Aceh

mengakumulasi lumpur seperti penggunaan tiang bambu pada metode stick. Menurut Rejeki (2001) dan Sreedevi et al. (2014), akumulasi lumpur pada metode stick dapat menurunkan laju filtrasi kerang hijau, sehingga masuknya makanan ke dalam tubuhnya akan terganggu. Dari penelitian ini dapat disimpulkan bahwa budidaya kerang hijau dengan metode dan kepadatan yang berbeda berpengaruh signifikan dan ada interaksi antara kedua faktor tersebut terhadap SGR (W) dan SGR (L). Beberapa faktor yang penting dan berkontribusi dalam pengembangan budidaya kerang hijau antara lain adalah kondisi hidrologi perairan (Velayudhan et al., 2000), ketersediaan benih dari alam (Asokan et al., 2001), serta modal produksi dari bank ataupun nonbank (Vipinkumar et al., 2001).

Penelitian yang dilakukan oleh Sreedevi et al. (2014) menunjukkan bahwa kerang hijau yang dibudidayakan menggunakan metode of-bottom (long line) dengan panjang awal 1,9 $\pm 0,2 \mathrm{~cm}$ dengan bobot 2,23 \pm $0,09 \mathrm{~g}$ yang dipelihara selama 60 hari mengalami peningkatan panjang menjadi $3,1 \pm 0,4 \mathrm{~cm}$ dengan bobot akhir sebesar 4,61 $\pm 0,08 \mathrm{~g}$; dengan laju pertumbuhan spesifik sebesar 3,06 g/bulan hingga 4,50 g/bulan. Menurut Garen et al. (2004), penerapan meto de budidaya yang berbeda pada kerang hijau akan memengaruhi baik panjang maupun bobot secara signifikan, di mana berdasarkan penelitian yang dilakukan di Pertuis Breton, Perancis menunjukkan budidaya dengan metode long line memiliki performa pertumbuhan yang lebih baik dibandingkan dengan metode budidaya dengan metode on-bottom.
Spesies yang sama pada lokasi yang berbeda memiliki pertumbuhan yang berbeda pula, karena adanya faktor dalam maupun faktor luar yang memengaruhi pertumbuhan biota tersebut. Faktor dalam meliputi faktor yang sulit dikontrol seperti genetik, umur, parasit, dan penyakit, sedangkan faktor luar yang utama memengaruhi pertumbuhan seperti kualitas perairan dan ketersediaan makanan dari alam (Kripa et al., 2009). Ukuran cangkang kerang juga dipengaruhi oleh fluktuasi faktor lingkungan, sedangkan bentuk cangkang lebih dipengaruhi oleh faktor genetik (Ramesha \& Thippeswamy, 2009). Garen et al. (2004), juga menyebutkan bahwa pertumbuhan kerang khususnya pada cangkang dan jaringan dapat dipengaruhi oleh kepadatan populasi, faktor fisik, kimia maupun biologis, dan habitat.

Hasil analisis data plankton menunjukkan bahwa plankton yang ditemukan selama periode budidaya terdiri atas fitoplankton $(84,79 \%$ dan zooplankton $(15,21 \%$. Plankton yang teridentifikasi sebanyak 53 genus yang terdiri atas 34 genus fitoplankton dan 19 genus zooplankton. Fitoplankton mencakup empat kelas dengan komposisi dari yang tertinggi sampai terendah yaitu kelas Bacillariophyceae $(89,12 \%)$, Dinophyceae $(6,33 \%)$, Cyanophyceae $(3,23 \%)$, dan Desmidiaceae $(1,32 \%$, sedangkan zooplankton hanya terdiri atas satu kelas yaitu Crustacea (100\%). Kelimpahan fitoplankton tertinggi diwakili oleh jenis Skeletonema sp. yaitu 211.750 individu $/ \mathrm{m}^{3}$ dan terendah jenis Noctiluca dengan kelimpahan 2.000 individu/ $\mathrm{m}^{3}$, sedangkan kelimpahan zooplankton tertinggi diwakili 
oleh jenis Calanus sp. sebesar 8.481 individu $/ \mathrm{m}^{3}$ dan terendah diwakili oleh jenis Undinula dengan kelimpahan 1.703 individu/m³.

Melimpahnya fitoplankton dibandingkan dengan zooplankton diduga terkait dengan beberapa parameter lingkungan yang berada dalam kisaran optimal untuk mendukung kehidupan fitoplankton tersebut, seperti cahaya, suhu, dan zat hara yang menyebabkan pertumbuhan fitoplankton lebih cepat. Nontji (1993), menjelaskan bahwa Bacilariophyceae merupakan kelas fitoplankton pada kelompok diatom yang paling melimpah di perairan diduga karena sifatnya yang kosmopolit di berbagai kondisi perairan dan merupakan kelompok fitoplankton yang penting dalam rantai makanan.

Kelimpahan plankton di pesisir Kuala Langsa diduga sangat memengaruhi laju pertumbuhan kerang hijau yang dibudidayakan pada perairan tersebut. Menurut Gosling (2003), ketersediaan dan kelimpahan makanan bagi kerang dapat memengaruhi pertumbuhan jaringan, penyimpanan dan penggunaan makanan yang dapat mengubah rasio bo bot badan terhadap panjang cangkang. Kebiasaan makan kerang dapat dihubungkan dengan makanan di perairan di mana kerang tersebut hidup, dengan komponen nutrien yang penting bagi pertumbuhan (Helm et al., 2004).

Kerang hijau merupakan organisme filter feeder, di mana cara mendapatkan makanan dengan memompa air melalui rongga mantel, sehingga mendapatkan partikel-partikel yang ada di dalam air. Mikroalga merupakan makanan utamanya, sedangkan makanan tambahan berupa zooplankton, zat organik terlarut dan bakteri. Kelimpahan Skeletonema sp. di perairan pesisir Kuala Langsa tergolong tinggi (211.750 individu $/ \mathrm{m}^{3}$ ). Penelitian yang dilakukan Suryono et al. (1999) menyebutkan bahwa mikroalga Skeletonema sp. merupakan jenis yang paling banyak diserap kerang hijau. Kecepatan filtrasi oleh kerang hijau pada semua ukuran terhadap Skeletonema sp. lebih tinggi dibandingkan terhadap Chlorella sp. (Praktikto, 2013).

Penelitian Rajesh et al. (2001) menyebutkan bahwa adanya hubungan panjang cangkang kerang dengan kecepatan filtrasi, di mana semakin panjang cangkang kerang maka semakin besar kecepatan filtrasinya. Penelitian lainnya menyebutkan laju filtrasi kerang dipengaruhi oleh ukuran partikel/sel, kepadatan dan kualitas plankton, ukuran kerang dan faktor lingkungan (Riisgard, 2001a), sedangkan faktor lingkungan yang memengaruhi laju filtrasi antara lain oksigen terlarut, $\mathrm{pH}$, suhu, salinitas, dan partikel tersuspensi, serta klorofil-a (Riisgard, 2001b). Penelitian mengenai laju filtrasi dan efisiensi penyerapan kerang hijau menunjukkan bahwa kerang hijau sanggup menyaring partikel minimum 0,64 $\mu \mathrm{m}$ (Gosling, 2003).

Faktor yang juga penting dalam mendukung laju pertumbuhan kerang hijau yaitu faktor ekologis perairan. Faktor lingkungan merupakan parameter penting karena memengaruhi kebutuhan dan asupan pakan, sehingga berpengaruh terhadap laju pertumbuhan kerang (Pattikawa \& Ferdinandus, 2009). Kondisi ekologis perairan pesisir Kuala Langsa selama periode budidaya dikategorikan masih dalam kondisi baik dan mendukung pertumbuhan kerang hijau. Kondisi parameter perairan pesisir Kuala Langsa selama periode budidaya kerang hijau tersaji pada Tabel 3.

Tabel 2 menunjukkan bahwa suhu berkisar $27,5^{\circ} \mathrm{C}$ $34,0^{\circ} \mathrm{C}$; beberapa penelitian sebelumnya menyebutkan suhu optimal untuk mendukung pertumbuhan kerang hijau adalah $27^{\circ} \mathrm{C}-30^{\circ} \mathrm{C}$ (Aypa, 1990$) ; 26^{\circ} \mathrm{C}-32^{\circ} \mathrm{C}$ (Hickman, 1992). Nair et al. (2003) menyebutkan bahwa berdasarkan hasil penelitian di daerah tropis, kerang hijau akan mati dalam waktu 30 menit pada suhu $43^{\circ} \mathrm{C}$. Salinitas pada lokasi budidaya kerang hijau di perairan pesisir Kuala Langsa berkisar 28,5-33,0 ppt. Menurut McGuire \& Stevely (2009), kerang hijau masih dapat

Tabel 3. Parameter kualitas perairan selama periode budidaya kerang hijau di perairan pesisir Kuala Langsa, Aceh

Table 3. Water quality data during culture period of green mussel in coastal waters Kuala Langsa, Aceh

\begin{tabular}{lccc}
\hline \multicolumn{1}{c}{$\begin{array}{c}\text { Parameter } \\
\text { Parameters }\end{array}$} & $\begin{array}{c}\text { Satuan } \\
\text { Unit }\end{array}$ & $\begin{array}{c}\text { Nilai kisaran } \\
\text { Range value }\end{array}$ & $\begin{array}{c}\text { Rata-rata } \pm \text { SD } \\
\text { Average } \pm \text { SD }\end{array}$ \\
\hline Suhu (Temperature) & ${ }^{\circ} \mathrm{C}$ & $27.5-34.0$ & $30.2 \pm 1.68$ \\
Salinitas (Salinity) & $\mathrm{ppt}$ & $28.5-33.0$ & $30.0 \pm 1.06$ \\
pH (Acidity) & - & $7.8-8.6$ & $8.1 \pm 0.19$ \\
Oksigen terlarut (Dissolved oxygen) & $\mathrm{mg} / \mathrm{L}$ & $4.5-6.5$ & $5.6 \pm 0.50$ \\
Kecepatan arus (Current velocity) & $\mathrm{m} / \mathrm{s}$ & $0.1-0.3$ & $0.2 \pm 0.08$ \\
\hline
\end{tabular}


hidup pada kisaran salinitas antara $15-45$ ppt. Salinitas tinggi (24 hingga 30 ppt) meningkatkan laju filtrasi kerang hijau (Rajesh et al., 2001). FIGIS (2005) juga menjelaskan bahwa kerang hijau menunjukkan pertumbuhan yang baik pada habitat estuari dengan kisaran salinitas 18-33 ppt. Salinitas 24-30 ppt secara signifikan meningkatkan indeks kondisi kerang (Kripa et al., 2009). Konsentrasi oksigen terlarut selama periode budidaya kerang hijau berkisar 4,5-6,5 mg/L. Menurut Alfaro (2005), konsentrasi oksigen terlarut yang masih dapat ditoleran kerang hijau berkisar 2-12 mg/L. Tingkat keasaman atau $\mathrm{pH}$ di perairan budidaya kerang hijau berkisar 7,8-8,6. Menurut Sreedevi et al. (2014), pH yang masih dapat ditoleran kerang hijau berkisar 7-9. Kecepatan arus perairan selama periode budidaya kerang hijau berkisar 0,1$0,3 \mathrm{~m} / \mathrm{s}$. Kecepatan arus yang sesuai untuk kegiatan budidaya kerang hijau berkisar 0,1 hingga $0,6 \mathrm{~m} / \mathrm{s}$ (Alfaro, 2005; FIGIS, 2005).

\section{KESIMPULAN}

Budidaya kerang hijau di pesisir Kuala Langsa, Aceh dengan metode long line dan kepadatan 20 individu/ kantong 5,30 L menunjukkan hasil yang paling optimal, di mana rata-rata nilai SGR (L) sebesar 0,86 \pm $0,01 \%$ hari sedangkan untuk nilai SGR (W) sebesar 1,18 \pm 0,04\%

\section{UCAPAN TERIMA KASIH}

Terima kasih disampaikan kepada Program Studi Pengelolaan Sumberdaya Pesisir dan Lautan, Departemen Manajemen Sumberdaya Perairan, Institut Pertanian Bogor, yang telah banyak membantu dalam proses administrasi selama penelitian, serta Dinas Kelautan, Perikanan dan Pertanian Kota Langsa yang telah membantu dalam pelaksanaan penelitian.

\section{DAFTAR ACUAN}

Acosta, V., Glem, M.E., Natera, Y., Urbano, T., Himmelman, J.H., Rey-Mende, M., \& Lodeiron, C. (2009). Differential growth of the mussel Perna perna and Perna viridis (Bilvalvia : Mytilidae) in suspended culture in the Golfo de Cariaco, Venezuela. Journal World Aquaculture Society, 40, 226-235.

Alfaro, A.C. (2005). Effect of water flow and oxygen concentration on early settlement of the New Zealand green-lipped mussel Perna canalicus. Aquaculture, 246, 285-294.

Asokan, P.K., Vipinkumar, V.P., Appukuttan, K., Surendranathan, V.G., \& Sivadasan, M.P. (2001). Mussel culture in backwaters of Kasargod District Kerala. Marine Fisheries Information T \& E, 169, 911.
Aypa, S.M. (1990). Mussel culture : regional sea farming development and demonstration project. Bangkok : National Inland Fisheries Institute, Kasetsart University.

Cheney, D.P. (2010). Bivalve shellfish quality in the USA: from the hatchery to the consumer. Journal of Aquaculture Society, 41(2), 192-205.

Costa-Pierce, B. (2008). An ecosystem approach to marine aquaculture: a global review. In Soto, D., Aguilar-Manjarrez, J., \& Hishamunda, N. (Eds.). Building an ecosystem approach to aquaculture. FAO Fisheries and Aquaculture Proceedings, 14, 81155.

Davis, C.C. (1955). The marine and fresh-water plankton. USA: Michigan State University Press.

Ellis, J., Cummings, V., Hewitt, J., Thrush, S., \& Norkko, A. (2002). Determining effect of suspended sediment on condition of a suspension feeding bivalve (Atrina zelandica): results of a survey, a laboratory experiment and a field transplant experiment. Journal of Experimental Marine Biology and Ecology, 267, 147-174.

Fisheries Global Information System [FIGIS]. (2005). Species fact sheet : Perna viridis (Linnaeus, 1758)Mytilidae. Rome : FAO.

Garen, P., Robert, S., \& Bougrier, S. (2004). Comparison of growth of mussel, Mytilus edulis, on longline, pole and bottom culture sites in the Pertuis Breton, France. Aquaculture, 232, 511-524.

Garr, A.L., Lopez, H., Pierce, R., \& Davis, M. (2011). The effect of stocking density and diet on the growth and survival of culture florida apple snails, Pomacea paludosa. Aquaculture, 311, 139-145.

Gosling, E. (2003). Bivalve molluscs biology, ecology and culture. Amsterdam: Elsevier.

Helm, M.M., Bourne, N., \& Lovatelli, A. (2004). Hatchery culture of bivalves: A practical manual. Rome: FAO.

Hickman, R.W. (1992). Mussel cultivation. In Gosling, E. (Ed.) (2003). The mussel mytilus: ecology, physiology, genetics and culture. Amsterdam: Elsevier.

Hopkins, K.D. (1992). Reporting fish growth: A review of the basics. Journal World Aquaculture Society, 23, 173-179.

Huntingford, F., \& Damsgard, B. (2012). Fighting and aggression. In Huntingford, F., Jobling, M., \& Kardi, S. (Eds.). Aquaculture and Behavior. Oxford: A John Wiley \& Sons.

Kripa, V., \& Mohamed, K.S. (2008). Green mussel, Perna viridis, farming in Kerala India-technology diffusion process and socio-economic impacts. Journal of the World Aquaculture Society, 39, 612634. 
Kripa, V., Mohamed, K.S., Velayudhan, T.S., Joseph, M., Alloycious, P.S., \& Sharma, J. (2009). Comparison of growth and gonad development of farmed green mussel Perna viridis $L$. in three habitats. Journal of Marine Biological Association of India, 51, 199-204.

Leimena, H.E.P., Tati-Subadar, S.S., \& Adianto. (2005). Estimasi daya dukung dan pola pertumbuhan populasi kerang Iola (Trocus niloticus) di Pulau Saparua Maluku Tengah. Jurnal Matematika dan Sains, 10, 75-80.

Luo, G., Liu, G., \& Tan, H. (2013). Effect of stocking density and food deprivation-related stress on the physiology and growth in adult Scortum barcoo (McCulloch \& Waite). Aquaculture Research, 44, 885894.

Magondu, E.W., Charo-Karisa, H., \& Verdegem, M.C.J. (2013). Effect $\mathrm{C} / \mathrm{N}$ ratio levels and stocking density of Labeo victorianuson pond environmental quality using maize flour as a carbon source. Aquaculture, 411, 157-163.

Manley, C.B., Rakocinski, C.F., Lee, P.G., \& Blaylock, R.B. (2014). Stocking density effect on aggressive and cannibalistic behaviors in larval hatchery-reared spotted seatrout Cynoscion nebulosus. Aquaculture, 420-421, 89-94.

McGuire, M., \& Stevely, J. (2009). Invasive species of Florida's coastal waters : the asian green mussel (Perna viridis). USA: The Florida Sea Grant College Program with support from the National Oceanic and Atmospheric Administration, U.S. Department of Commerce.

Nair, K.V.K., Manoj, R., \& Appukuttan, K.K. (2003). Effect of temperature on the development, growth, survival and settlement of green mussel Perna viridis (Linnaeus, 1758). Aquaculture Research, 34, 137-145.

Nontji, A. (1993). Laut Nusantara. Jakarta: Djambatan.

Pattikawa, J.A., \& Ferdinandus, E. (2009). Growth of mangrove cockle (Anadara antiquata) cultured in cage. Marine Research Indonesia, 34, 91-96.

Praktikto, I. (2013). Filtrasi kerang hijau (Perna viridis) terhadap mikroalga pada jenis dan konsentrasi berbeda. Buletin Oseanografi Marina, 2, 35-40.

Rajagopal, S., Venugopalan, V.P., Van der Velde, G., \& Jenner, H.A. (2003). Response of fouling brown mussel (Perna perna L.) to chlorine. Archives of Environmental Contamination and Toxicology, 44, 269276.

Rajesh, K.V., Mohamed, K.S., \& Kripa, V. (2001). Influence of algal cell concentration, salinity and body size on the filtration and ingestion rates of cultivable Indian bivalves. Indian Journal MarineScience, 30, 87-92.
Ramesha, M.M., \& Thippeswamy, S. (2009). Allometry and condition index in the freshwater bivalve Parreysia corrugate (Muller) from river Kempuhole, India. Asian Fisheries Science, 22, 203-214.

Rejeki, S. (2001). Pengantar budidaya perairan. Semarang: Badan Penerbit Universitas Diponegoro.

Riisgard, H.U. (2001a). On measurement of filtration rate in bilvalve-the stony road to reliable data: review and interpretation data. Marine Ecology Progress Series, 221, 275-291.

Riisgard, H.U. (2001b). Inaccurate bilvalve clearance rate measurements: A reply. MarineEcology Progress Series, 22, 307-309.

Sallih, K. (2005). Mussel farming in The State of Sarawak, Malaysia: A feasibility study. The United Nation University: Final Project of Fisheries Training Programme.

Shumway, S.E., Davis, C., Downey, R., Karney, R., Kraeuter, J., Parson, J., \& Wikfors, G. (2003). Shellfish aquaculture in praise of sustainable economies and environments. World Aquaculture, 34, 1517.

Soon, T.K., \& Ransangan, J. (2014). A review of feeding behavior, growth, reproduction and aquaculture site selection for green-lipped mussel, Perna viridis. Advances in Bioscience and Biotechnology, 5, 462-469.

Sreedevi, P.R., Uthayakumar, V., Jayakumar, R., Joseph, P., Kumar, D.S., \& Ramasubramanian, V. (2014). Comparative valuation of on-bottom and off bottom mussel (Perna viridis) culture as a small scale enterprise in Chettuva Estuary at Kerala India. World Journal of Fish and Marine Science, 6, 487493.

Suryono, Suryono, C.A., \& Irwani. (1999). Kecepatan filtrasi berbagai ukuran kerang hijau Perna viridis terhadap beberapa jenis mikroalga. IImu Kelautan, 4, 196-201.

Vakily, J.M. (1989). The biology and culture of mussels of the genus Perna. Manila: International Center for Living Aquatic Resources Management.

Velayudhan, T., Kripa, S.V., Appukuttan, K.K., Mohamed, K.S., \& Laxmilatha, P. (2000). Feasibility of integrated bivalve farming in an estuarine system of Central Kerala, India. In Tiensongrasmee, B., Tedengren, M., Jarayabhand, P., Tandavanitj, N., Popongviwat, A, Nujsawat, A., \& Soisodsri, S. (Eds.). Mollusca Research in Asia. Bangkok: Thailand Research Fund.

Vipinkumar, V.P., Asokan, P.K., \& Appukuttan, K.K. (2001). Mussel farming by women self help groups in Kasargod district: A case study. Marine Fisheries Information Service T \& E Series, 169, 4-6. 
Lampiran 1. Sidik ragam data SGR (L) kerang hijau yang dibudidayakan dengan metode dan kepadatan berbeda di perairan pesisir Kuala Langsa, Aceh

Appendix 1. Analysis of variance of data SGR (L) green mussel are cultured with different of method and densities in coastal waters Kuala Langsa, Aceh with different of method and densities in coastal waters Kuala Langsa, Aceh

\begin{tabular}{lccccc}
\hline $\begin{array}{c}\text { Sumber keragaman } \\
\text { Source of variation }\end{array}$ & $\begin{array}{c}\text { Jumlah kuadrat } \\
\text { Sum of square }\end{array}$ & $\begin{array}{c}\text { Derajat bebas } \\
\text { Degree of free }\end{array}$ & $\begin{array}{c}\text { Meadrat tengah of square } \\
\text { Den }\end{array}$ & $\begin{array}{c}\text { F hitung } \\
\mathbf{F}\end{array}$ & $\begin{array}{c}\text { F tabel }(\mathbf{0 , 0 5}) \\
\mathbf{F} \text { table }(\mathbf{0 . 0 5})\end{array}$ \\
\hline Metode (M ethod) (A) & 0.0177 & 1 & 0.01766 & $2,589.415^{*}$ & 4.414 \\
Kepadatan (Densities) (B) & 0.0090 & 2 & 0.00451 & $661.912^{*}$ & 3.555 \\
Interaksi (Interaction) (A x B) & 0.0002 & 2 & 0.00010 & $15.232^{*}$ & 3.555 \\
Galat (Error) & 0.0001 & 18 & 0.00001 & & \\
Total (Total) & 0.0270 & 23 & & & \\
\hline
\end{tabular}

Keterangan (Note): ${ }^{*} \mathrm{~F}$ hitung $>\mathrm{F}$ tabel $(\mathrm{P}<0,05) \rightarrow$ berbeda signifikan $(* \mathrm{~F}>\mathrm{F}$ table $(\mathrm{P}<0.05) \rightarrow$ significantly different)

Lampiran 2. Sidik ragam data SGR (W) kerang hijau yang dibudidayakan dengan metode dan kepadatan berbeda di perairan pesisir Kuala Langsa, Aceh

Appendix 2. Analysis of variance of data SGR (W) green mussel are cultured with different of method and densities in coastal waters Kuala Langsa, Aceh

\begin{tabular}{lccccc}
\hline $\begin{array}{c}\text { Sumber keragaman } \\
\text { Source of variation }\end{array}$ & $\begin{array}{c}\text { Jumlah kuadrat } \\
\text { Sum of square }\end{array}$ & $\begin{array}{c}\text { Derajat bebas } \\
\text { Degree of free }\end{array}$ & $\begin{array}{c}\text { Mean of square } \\
\text { Menat tengah }\end{array}$ & $\begin{array}{c}\mathbf{F} \text { hitung } \\
\mathbf{F}\end{array}$ & $\begin{array}{c}\mathbf{F} \text { tabel }(\mathbf{0 , 0 5}) \\
\mathbf{F} \text { table }(\mathbf{0 . 0 5})\end{array}$ \\
\hline Metode (M ethod) (A) & 0.0915 & 1 & 0.09151 & $1,541.640^{*}$ & 4.414 \\
Kepadatan (Densities) (B) & 0.0193 & 2 & 0.00963 & $162.250^{*}$ & 3.555 \\
Interaksi (Interaction) (A X B) & 0.0022 & 2 & 0.00110 & $18.510^{*}$ & 3.555 \\
Galat (Error) & 0.0011 & 18 & 0.00006 & & \\
Total (Total) & 0.1140 & 23 & & & \\
\hline
\end{tabular}

Keterangan (Note): $* \mathrm{~F}$ hitung $>\mathrm{F}$ tabel $(\mathrm{P}<0,05) \rightarrow$ berbeda signifikan $(* \mathrm{~F}>\mathrm{F}$ table $(\mathrm{P}<0.05) \rightarrow$ significantly different)

Lampiran 3. Sidik ragam data sintasan kerang hijau yang dibudidayakan dengan metode dan kepadatan berbeda di perairan pesisir Kuala Langsa, Aceh

Appendix 3. Analysis of variance of survival rate green mussel are cultured with different of method and densities in coastal waters Kuala Langsa, Aceh

\begin{tabular}{lccccc}
\hline $\begin{array}{c}\text { Sumber keragaman } \\
\text { Source of variation }\end{array}$ & $\begin{array}{c}\text { Jumlah kuadrat } \\
\text { Sum of square }\end{array}$ & $\begin{array}{c}\text { Derajat bebas } \\
\text { Degree of free }\end{array}$ & $\begin{array}{c}\text { Kuadrat tengah of square } \\
\text { Mean }\end{array}$ & $\begin{array}{c}\text { F hitung } \\
\text { F tabel }(\mathbf{0 , 0 5})\end{array}$ & $\mathbf{F}$ table $(\mathbf{0 . 0 5})$ \\
\hline Metode (M ethod) (A) & 2.894 & 1 & 2.894 & 0.265 & 4.414 \\
Kepadatan (Densities) (B) & 477.083 & 2 & 238.542 & $21.848^{*}$ & 3.555 \\
Interaksi (Interaction) (Ax B) & 14.120 & 2 & 7.060 & 0.647 & 3.555 \\
Galat (Error) & 196.528 & 18 & 10.918 & & \\
Total (Total) & 690.625 & 23 & & & \\
\hline
\end{tabular}

Keterangan (Note): $* \mathrm{~F}$ hitung $>\mathrm{F}$ tabel $(\mathrm{P}<0,05) \rightarrow$ berbeda signifikan $(* \mathrm{~F}>\mathrm{F}$ table $(\mathrm{P}<0.05) \rightarrow$ significantly different) 
Lampiran 4. Hasil uji BNT data SGR (L)

Appendix 4. Least significant difference (LSD) of data SGR (L)

\begin{tabular}{cccccccc}
\hline $\begin{array}{c}\text { Nilai } \\
\text { Value }\end{array}$ & $\begin{array}{c}\text { Perlakuan } \\
\text { Treatments }\end{array}$ & A1B1 & A1B2 & A1B3 & A2B1 & A2B2 & A2B3 \\
\hline 0.860 & A1B1 & 0 & & & & & \\
0.828 & A1B2 & $0.032 *$ & 0 & & & & \\
0.822 & $\mathrm{~A} 1 \mathrm{~B} 3$ & $0.038^{*}$ & $0.006 *$ & 0 & & & \\
0.813 & $\mathrm{~A} 2 \mathrm{~B} 1$ & $0.047 *$ & $0.015^{*}$ & $0.009 *$ & 0 & & \\
0.775 & $\mathrm{~A} 2 \mathrm{~B} 2$ & $0.085 *$ & $0.053^{*}$ & $0.047^{*}$ & $0.038^{*}$ & 0 & \\
0.760 & $\mathrm{~A} 2 \mathrm{~B} 3$ & $0.100^{*}$ & $0.068^{*}$ & $0.062^{*}$ & $0.015^{*}$ & $0.015^{*}$ & 0 \\
\hline
\end{tabular}

Keterangan (Note): * Berbeda sangat signifikan pada taraf uji 5\%(Very significantly different to the $5 \%$ test level)

Lampiran 5. Hasil uji BNT data SGR (W)

Appendix 5. Least significant difference (LSD) of data SGR (L)

\begin{tabular}{cccccccc}
\hline $\begin{array}{c}\text { Nilai } \\
\text { Value }\end{array}$ & $\begin{array}{c}\text { Perlakuan } \\
\text { Treatments }\end{array}$ & A1B1 & A1B2 & A1B3 & A2B1 & A2B2 & A2B3 \\
\hline 1.184 & A1B1 & 0 & & & & & \\
1.145 & A1B2 & $0.039 *$ & 0 & & & & \\
1.099 & A1B3 & $0.085^{*}$ & $0.046^{*}$ & 0 & & & \\
1.054 & A2B1 & $0.130^{*}$ & $0.091^{*}$ & $0.045^{*}$ & 0 & & \\
1.002 & A2B2 & $0.182^{*}$ & $0.143^{*}$ & $0.097^{*}$ & $0.052^{*}$ & 0 & \\
1.002 & A2B3 & $0.182^{*}$ & $0.143^{*}$ & $0.097^{*}$ & $0.052 *$ & 0 & 0 \\
\hline
\end{tabular}

Keterangan (Note):* Berbeda sangat signifikan pada taraf uji 5\%(Very significantly different to the $5 \%$ test level) 